TURIZAM

Volume 21, Issue 3

139-150 (2017)

ORIGINAL

SCIENTIFIC PAPER

\title{
The A'jarang Festival - an Innovative Effort for Regional Tourism Development in Jeneponto Regency (Indonesia)
}

\author{
Itham Junaid ${ }^{A *}$, Anne-Marie D'Hauteserre ${ }^{B}$ \\ Received: October 2017 | Accepted: December 2017 \\ DOI: 10.5937/turizam21-16113
}

\begin{abstract}
Innovation in all sectors of development has been the major concern of the Indonesian government including in tourism. Residents, however, are sceptical because Jeneponto regency is a dry area and thus has limited tourism potential. This paper aims at examining whether or not the A'jarang festival is an innovative way to inhance tourism; proposing efforts or strategies to support the festival as tourism innovation; and recommending approaches that can encourage the local government to implement more innovative ways for regional tourism development.

The article is based on a qualitative study conducted in 2016. The study reveals that although strategies are needed to support the A'jarang festival, it is considered an innovative effort. The festival should be managed based on the principles of products, processes, markets and managerial innovations. This paper underlines the importance of providing a representative venue and implementing iconic culinary tourism, conferences and seminars, cultural events and creative industries. The local board of tourism needs to strengthen its relationship with eight different community groups including the central and regional government, local leaders, the tourism industry, cultural activists, local community members, academics, non-tourism government institutions and the media.
\end{abstract}

Key words: The A'jarang festival, innovation, Jeneponto regency, Indonesia

\section{Introduction}

Challenges and obstacles faced by most developing countries in the world are the main reason why innovation is essential for tourism development including Indonesia. Hjalager (2009) argues that countries in the world are forced to implement innovative strategies in overcoming the challenges as well as to attract international tourists. Since many countries are promot-

A APoliteknik Pariwisata Makassar Jl. Gunung Rinjani, Kota Mandiri Tanjung Bunga, Makassar, South Sulawesi, Indonesia

B BThe University of Waikato, Gate 1 Knighton Road, Private Bag 3105, Hamilton 3240, New Zealand,

Email: adhautes@waikato.ac.nz

* Corresponding author: illank77@yahoo.co.id 
ing themselves, competition cannot be avoided (Fyall, Garrod, 2005; Mariani et al., 2014; Ritchie, Crouch, 200o). The Ministry of Tourism of the Republic of Indonesia targets 20 million international tourists for 2019. For this reason, a tourism destination should be able to maintain regular visits by previous tourists as well as to attract new tourists.

South Sulawesi is one of provinces in Indonesia that promotes its tourism potential through the role of the local board of tourism and culture. There are twenty-one regencies (kabupaten) and three cities (kota) in South Sulawesi; one of them is Jeneponto regency, located in the eastern part of South Sulawesi province. Neighbouring destinations such as Takalar and Bantaeng regencies also promote their areas which has forced Jeneponto to consider attracting tourists. However, residents in South Sulawesi are sceptical that Jeneponto has tourism potential. Thus, the local board of tourism and culture is challenged to find new strategies to approach tourists so they choose Jeneponto as part of their trip to Sulawesi.

The question arises on how to encourage visitors to choose Jeneponto as their destination instead of neighbouring areas. The residents' scepticism has encouraged the authors to investigate the role of the local government in developing tourism and to propose ways to optimise tourism potential in Jeneponto Regency. In 2016, the local government through the local board of tourism and culture conducted the A'jarang Festival, as an event to support tourism. This event has raised a number of questions; 1 ) Is it an innovative strategy to change people's mind about Jeneponto regency? 2) What forms of innovation support the establishment of the A'jarang Festival? What should the regional government do to develop tourism in Jeneponto regency? These questions guided the authors in understanding the A'jarang festival under the framework of tourism innovation. Based on the three questions, this paper aims at examining whether or not the A'jarang festival is an innovative way to inhance tourism; proposing efforts or strategies to support the festival as tourism innovation; and recommending approaches that can encourage the local government to implement more innovative ways for regional tourism development.

\section{Study Area and a Brief Description of the A'jarang Festival}

Jeneponto regency is well recognised with its "horse" ( $k u d a$ in Bahasa Indonesia and Jarang in the local language), a brand that brings Jeneponto as the center of horses (Wangsyah, 2016). Horse meat is mostly consumed by Jeneponto people. Thus, it is not surprising that coto kuda

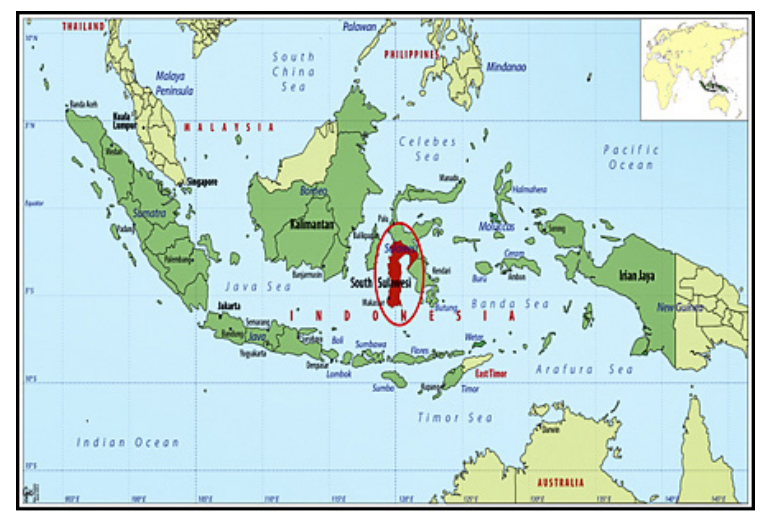

Figure 1. Map of Jeneponto regency of South Sulawesi province of Indonesia Source: map by Max Oulton, 2013 
(thick soup with horse meat as the main ingredient) becomes the icon of local cuisine. The authors sometimes heard from people that coto kuda is believed to act as medicine if people consume them. Although coto kuda is considered to be good for humans' health, not many people are interested to consume it. Visitors who are travelling in Jeneponto may see horses during their trip.

The government of Jeneponto realises that there should be efforts to change peoples' mind about Jeneponto. Karaeng (Mr.) Jalaluddin, the head of the local board of tourism and culture with his staff work to create events and activities to attract domestic and international tourists. Since the horse has become the icon of Jeneponto, A'jarang or Ajjarang festival (festival of horse or horse riding/racing) is the option for the local government to promote tourism potential. Three reasons for the establishment of the A'jarang festival include encouraging Jeneponto people's awareness and love for horses and horse farming; to inform local people that in addition to consuming horse, horse can become entertainment, an alternative form of income generation; to support and promote Jeneponto tourism through the A'jarang festival.

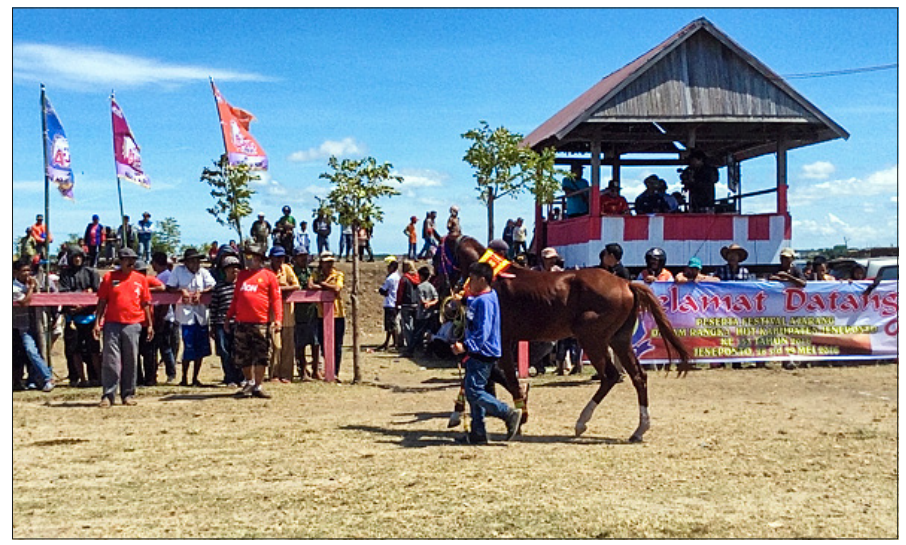

Figure 2. The A'jarang festival in Jeneponto regency Source: Authors, 2017

Three main activities were conducted in the A'jarang festival including a culinary festival, horse contests and horse racing. Contests of horses were interesting events that make the audience and participants very happy as various accessories were used on the horses. The jockeys sometimes instructed their horses to dance and show their physical talent to the juries. Fifty horses were involved in the contests when they showed different styles and performances. The participants in the horse racing were horse lovers from different areas in South Sulawesi and Southeast Sulawesi.

\section{Innovation and Tourism}

The concept of innovation was first introduced by Joseph Schumpeter in the 1940s. Until the 1970 researchers attempted to understand the link between innovation and efforts for development (Hjalager, 2009). The economic development of a country can be constituted through innovative strategies and/or efforts implemented by individuals or groups in organisations (Hjalager, 2006; Tejada, Moreno, 2013). Innovation is considered as a systematic process for developing various sectors (Mattsson et al., 2005) which many countries have used. Hjalager (2009) argues that Joseph Schumpeter's categorisation of innovation including product, pro- 
cess, managerial and market innovations is essential in encouraging other researchers in the world to recognise other issues related to innovation.

The tourism industries' innovative services and strategies for guests' satisfaction are essential in achieving a good quality trip. Hjalager (2006) affirms that the link between innovation and tourism is indicated by how tourism (through products and services) can encourage innovations as well as how innovations can help regions or destinations develop their tourism sector. Research in innovation and tourism focuses on how new knowledge and creativeness can be implemented in the tourism sector (Hjalager, 2006). Hence, investigating various issues in innovation (Shenoy, 2016) and tourism is essential in tourism research (Edwards et al., 2008).

Innovation can be understood as being of five types including "the creation of new products or services, new production processes, new markets, new suppliers and changed organisation or management systems" (Schumpeter, 1934 in Weiermair, 2006: 60). Such types indicate "something new or newness" in implementing strategies. Tourism also requires new products or services as mentioned in the first type. Tourism development also entails new processes or strategies, markets and organisational structures that can help achieve the target of tourism development. Cassela and Pashkevicha (2014) provide examples of new strategies or newness in giving visitors a more memorable experience for visitors when they attend cultural performances. They argue that innovative stories about a tourism product have been proved useful in providing added value for the tourists' visit.

The creation or the implementation of innovation is based on the work of members in organisations (Mei et al., 2013). "Innovation is a result of interaction between individuals and organisations rather than a linear process based on predetermined stages" (Cano, 2008:16). Li, et al. (2017) affirm that the capabilities of organisations (that consist of individuals) to implement innovation are essential in achieving the sustainable goals of institutions. Government as the main actor plays an important role in enhancing a destination to compete on national and international levels (Chaisawat, 2006; Dredge, 2001; Fernandes, 2013; Mei et al., 2013; Ruhanen, 2013; Veal, 2002). The establishment of a festival, for instance, depends on the role of the government. Many creative and innovative ways may come from the community, but their implementation should be linked to the regional government as policy maker.

\section{Linking Festival and Tourism}

A festival as a cultural event has been considered as one strategy to encourage community awareness of their culture (Sadd, 2009; Wood, Thomas, 2009). Since a festival is held based on the culture of the community, there is a possibility that it can enhance the community's understanding of their culture and the significance of tourism for their community, which is also linked to the community's quality of life (Cecil et al., 2010; Wood, Thomas, 2009). This is probably the reason why festivals have become a current trend in promoting the tourism potential of a destination (Lee, 2011; Salem et al., 2004).

Tourism stakeholders particularly the regional government expect that the conduct of a festival should bring more tourists to a destination. De Brito and Terzieva (2016) argue that the increasing numbers of festivals have encouraged stakeholders to organise events and festivals in a sustainable way. This will affect a tourism destination is developed through festivals and events. Since the visitors participate in a festival (seeing the attractions, taking pictures, gathering with community members), the chance to develop tourism is open for a destination. For cultural tourists, the expectations and motivation based on cultural knowledge can be achieved particularly if they attend a festival (Barbieri, Mahoney, 2010; Demonja, 2013; Griffin 
et al., 2013; Smith, 2003; Yang, 2011). The cultural identity and image of a destination can be seen in a festival, and thus, it is important for tourists to participate in activities that are held during a festival.

\section{Methodology and data}

Qualitative methodology guided the researchers in understanding the conduct of the A'jarang festival in South Sulawesi province of Indonesia. Snape and Spencer (2003) argue that qualitative research places the researcher as the observer of the phenomenon being studied. This is particularly reflected in the observation role of the authors in doing this research. The authors conducted participant observation by attending the A'jarang festival on May 28 to 29, 2016. The authors took notes or wrote in a diary after exploring the research area and attending the festival.

In-depth interviews to key informants, the head of the local board of tourism and culture of Jeneponto regency, the head of the promotion section and a staff were useful in understanding why and how the festival is implemented. The authors also conducted five informal interviews of community members who attended the festival. For a more comprehensive understanding about the festival and tourism development in Jeneponto regency, government documents were collected and analysed based on a qualitative approach. The authors also utilised the visit to hear the visitors' comments about the festival. Three domestic visitors were interviewed during the visit. The choice of research participants was based on the principle of purposive sampling, a method of sampling that focuses on the availability of the respondents and the purpose of the research. The interviews were conducted before the execution of the festival by visiting the office of the local board of tourism and culture. Before the interviews, the authors asked the staff if they were available and willing to participate. It is important for the interviewees to understand the goals of the research and thus, the authors explained them. This enabled the staff to participate in the research.

Data were analysed using data reduction. In particular, the authors employed thematic analysis to understand the qualitative information obtained from interviews, documents and participant observation. Spencer et al. (2003) argue that thematic summaries of the qualitative information enable the researchers to understand the meaning of the data through data categorisation and interpretation. Based on this principle, the authors provide examples of summaries that can be seen on the table 1 . 
Table 1. Summaries of qualitative data

\begin{tabular}{|c|c|}
\hline Themes/Topics & Issues covered \\
\hline The A'jarang festival & $\begin{array}{l}\text { - } \text { Horse as the icon of tourism } \\
\text { - } \text { Considered as innovative way } \\
\text { - Horse as the unique attraction for developing culinary tourism } \\
\text { - The rise of local tourism through festival } \\
\text { - Involving community through festival } \\
\text { - Way to involve community and to preserve culture } \\
\text { - Government's effort to obtain community support in government program } \\
\text { - Limited participation by the tourism industry } \\
\text { - } \text { It is necessary to provide facilities to support the festival }\end{array}$ \\
\hline Forms of innovation & $\begin{array}{l}\text { - } \text { Culinary art/product to support the festival } \\
\text { - } \text { The need to establish international scale events } \\
\text { - Traditional and creative products to support the festival } \\
\text { - Market innovation } \\
\text { - } \text { Product innovation } \\
\text { - Managerial innovation }\end{array}$ \\
\hline $\begin{array}{l}\text { The Local } \\
\text { government's role }\end{array}$ & $\begin{array}{l}\text { - Expectation to attract more visitors to Jeneponto regency } \\
\text { - } \text { Requires other events to support the festival } \\
\text { - To ineed to establish international scale events } \\
\text { - Strengthen coordination among the levels of government } \\
\text { - Partnership with academics (research, consultation) } \\
\text { - } \text { Working with the local leaders } \\
\text { - Regional autonomy shold not limit coordination among the levels of government } \\
\text { - Partnership with groups of community }\end{array}$ \\
\hline
\end{tabular}

Source: Authors, 2017

\section{Making the A'jarang Festival a National and International Scale Event}

Staff at the local board of tourism and culture, believe the A'jarang festival is an innovative strategy for two reasons. First, areas or destinations in Indonesia haven't conducted festivals or events related to horses in the perspective of tourism development. Similarities with other such festivals may exist in the world. However, for Jeneponto regency, horse is the icon of the area which most people in South Sulawesi province of Indonesia recognise. Hence, it is possible to attract tourists to come to Jeneponto through the A'jarang festival. Second, the festival can enhance communities' understanding that the horses can provide economic advantages, through tourism, for example. In an interview, the head of tourism and culture states "the strategic development of tourism in Jeneponto is by conducting cultural festivals, then the A'jarang festival has brought tourism to Jeneponto ; we want to encourage the government to support tourism in Jeneponto through festivals" (interview, 28 May 2016). For Smith (2003), a festival is considered part of the community celebration of their culture which means that a festival is part of the community's heritage.

The attendance of the communities in the festival indicates that they support the government's efforts to develop tourism through festivals. Communities participate in various roles such as selling snacks, foods and drinking water as well as participating in the horse festival. Nevertheless, the people who participate are limited to small scale economic activities. Indeed, roles in the tourism industry such as travel agent is essential to bring tourists to tour- 
ism attractions or destinations (Buhalis, Ujma, 2006; Theobald, 2005). However, participation by the tourism industry is very limited, only domestic visitors (the local community and participants who came from outside of Jeneponto regency) attended the festival.

The local government expects to encourage more tourists to Jeneponto regency. However, this requires more efforts to build the A'jarang festival as a national and international scale event. First, it is necessary to provide a venue that is representative for horse racing. The committee made a temporary horse racing in an area, a fifteen minute drive from the city of Jeneponto. The authors noted that infrastructure is the main problem for the establishment of the festival. Since the festival was conducted on a dry field (dry rice field), the visitors found difficulties to seek facilities such as toilet and rest area. Mallen and Adams (2008) argue that sport events require a venue that provides the visitors or the attendees access to supporting facilities.

Similarly, the A'jarang festival included traditional culinary art with horse meat as the main ingredient. However, a dry place tends to bring a lot of dust which then affects the hygiene of the food. The authors had the chance to observe the execution of the culinary festival. Culinary tourism can support innovation of the festival by designing more creative efforts. For instance, the committee can invite the community to sell creative or innovative culinary products. In order to achieve a national and international level, the culinary products should also pay attention to hygiene and sanitation of the foods. Competition of creativity or innovation in the culinary arts can be an option for the organisers to bring the festival to a national and international level. Horse meat (icon) can be the main ingredient for the event, linking the A'jarang festival with culinary tourism.

The local government of Jeneponto regency may attract national and international attention by establishing international conferences related to local tourism potential and animal-based farming and other related cultural and social phenomena. It is important to diffuse the existence of a regency or town with its cultural and natural potentials through national or international events. However, this approach can only be achieved if infrastructure and other facilities support the establishment of an event. In an interview, a respondent argues that we (the government) wish to make Jeneponto regency as the driver for tourism development in South Sulawesi (interview, July 2016). Facilities are essential to support Jeneponto regency to conduct national and international scale events.

Making creative industries is one of the strategies in enhancing community participation in tourism. The local government seems to not include creative industries at the A'jarang festival. A cultural event should include a competition of creative industries that emphasise tra-

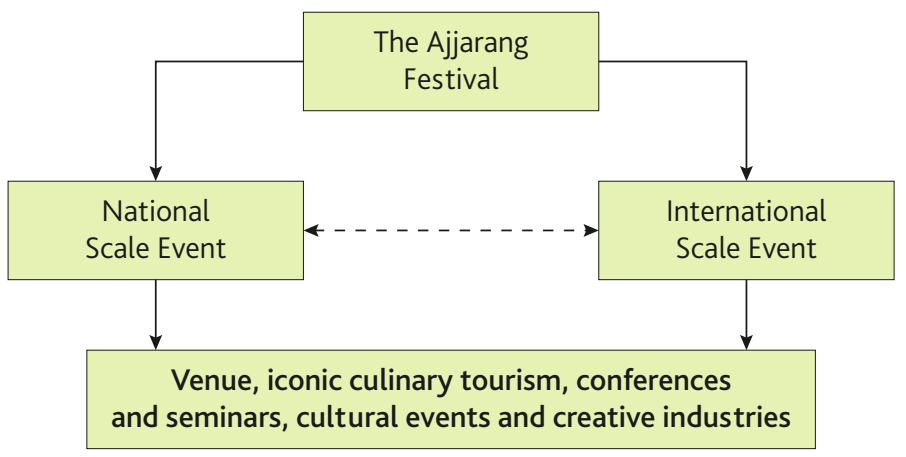

Figure 3. Bringing festival on national and international scale event Source: Authors, 2017 
ditional and creative products. In other words, bringing the A'jarang festival to a national and international scale should include innovative efforts, not just focusing on one single event. Figure 3 shows how to make the festival a national and international scale event.

\section{The A'jarang Festival From the Perspective of Tourism Innovation}

For Jeneponto regency, the festival is something different compared to attractions in other regencies that also conduct festivals for tourism development. The festival is considered as product innovation. Festivals or any tourism events should be executed based on the principle of innovation. A festival is part of a tourism product as the visitors attend and obtain experience about the socio-cultural condition of the destination. Hence, innovation is one of the keys in determining the success or the failure of tourism programs in a destination (Weidenfeld et al., 2016).

The process of innovation may occur if the local government as the main actor involves different service providers in establishing tourism events. The accommodation service provider for example, needs to be included in the creation of innovation. Festivals are intended not only for the visitors, rather, they need to be prepared by including the community, government employees, the tourism industry (business) and other related stakeholders. Weidenfeld and Leask (2016) argue that the process of innovation is based on the sharing of information, experience and knowledge by different people in a destination. They add that the way innovation is processed can be based on two approaches including incremental innovation, the organisers improve the existing tourism products particularly tourism events or festivals; and radical innovation, the organisers introduce new products to be promoted or proposed to potential tourists. The A'jarang festival can be developed based on some principles including the need to improve the quality of the festival, the importance of creating new strategies or efforts related to the festival and the need to involve different actors in the process of innovation.

From the perspective of innovation, it is important for the organisers of events to understand the market as well as how to promote the event in order to achieve the goals of regional tourism development. In conducting the A'Jarang festival, the organisers seem not to see markets as an essential component in the success of a tourism event. Marketing plays a pivotal role in building relationships with customers (Fyall, Garrod, 2005; Plog, 2005) especially if one considers promoting an event at the national and international level. Nevertheless, the market of the festival is limited to the regional scale. The organisers try to expand the market by inviting participants from outside of South Sulawesi. For Plog (2005), one should consider the market size, travel patterns, activities by the visitors, motivation and demographic and psychographics of the tourists.

The local government of Jeneponto regency provides the opportunity to event organiser (PT. Mide Indo Kreatif) to manage the event. For the local government, it is important to give responsibility to the event organiser to manage the event because it relates to the administration responsibility. Managerial system is one of the forms of innovation that the local government can implement. For instance, providing the opportunity for the government staff to manage the event by involving the local community instead of inviting an event organiser to organise the event. This approach enables the local community (non-government employees) to participate in the tourism event. 


\section{Linking Government and Community Groups for Innovative Festival}

To create innovation or innovative tourism festivals, the local board of tourism needs to strengthen relationships with eight different community groups. First, Indonesia has three levels of government including the national, regional (provincial) and local government. Since the implementation of regional autonomy (otonomi daerah) in 2001, the local government has the right to create programs and activities based on their priority. The regional autonomy should not decrease coordination among the levels of the government. Innovative efforts proposed by the local board of tourism should be supported by the national and regional governments in many ways, one of them being financial support. Similarly, tourism authorities at the national and regional levels should provide access or ability for local government to create innovative strategies in tourism.

Second, a festival should reflect and preserve the local culture of a tourism destination. To achieve this goal, approaching the local leader is essential as the voice of the local community. The role of the local leader is to facilitate the government to hear the expectation of the community concerning tourism events or festivals as well as the kind of festival that may come from the community. Mission statement of the local government is "the involvement of the community is needed in the sector of community service, give us your suggestion, aspiration and ideas about any government service including health, education, drinking water and sanitation". This statement indicates that the local government prioritises the community as part of its service. Hearing the community's ideas will thus be useful in creating innovative programs.

Third, the local board of tourism should strengthen partnership with academics. Innovative tourism festivals may come from academics because they conduct research. In particular, the relationship should emphasise the kinds of festivals that may be useful for regional tourism development based on recommendations by academics. Tourism development in a destination is a multi-sided approach that involves not only tourism institutions, but also non-tourism government institutions. The regent as the top manager of a regency supervises different government departments such as the local board of agriculture, the board of forestry and plantation, etc. The board of tourism and culture should work with other departments in planning and executing tourism innovations. This is the fourth approach that a regency should implement if innovative tourism programs are to be achieved. Examples can be seen in Bantaeng regency (about $50 \mathrm{kms}$ from the city of Jeneponto) where the regent implements integrated approaches to manage Marina beach as a tourism attraction.

Fifth, partnership between the local board of tourism and culture and media and the tourism industry should be strengthened. During the authors' visit in Jeneponto regency, information about the festival was limited. The inn where the authors stayed seemed to have little information about the festival. Yet, the staff of the board of tourism and culture promoted the event and recommended authors to visit. The tourism industry and media have the power to publish information about the festival. Sixth, cultural observers (cultural activists) and the community in general (traders, farmers, etc.) should be the pioneers of the innovative tourism programs. The A'jarang festival was pioneered by a government employee who loves culture, riding horses and is a member of the local community in Jeneponto regency. Possible innovative festivals can be created if the cultural activists, community and the local board of culture and tourism work together to discuss strategies to develop tourism under the framework of festivals and events. Maintaining a good relationship with cultural activists can be an alternative approach to help the community understand tourism which then contributes economic benefits for the local people. 


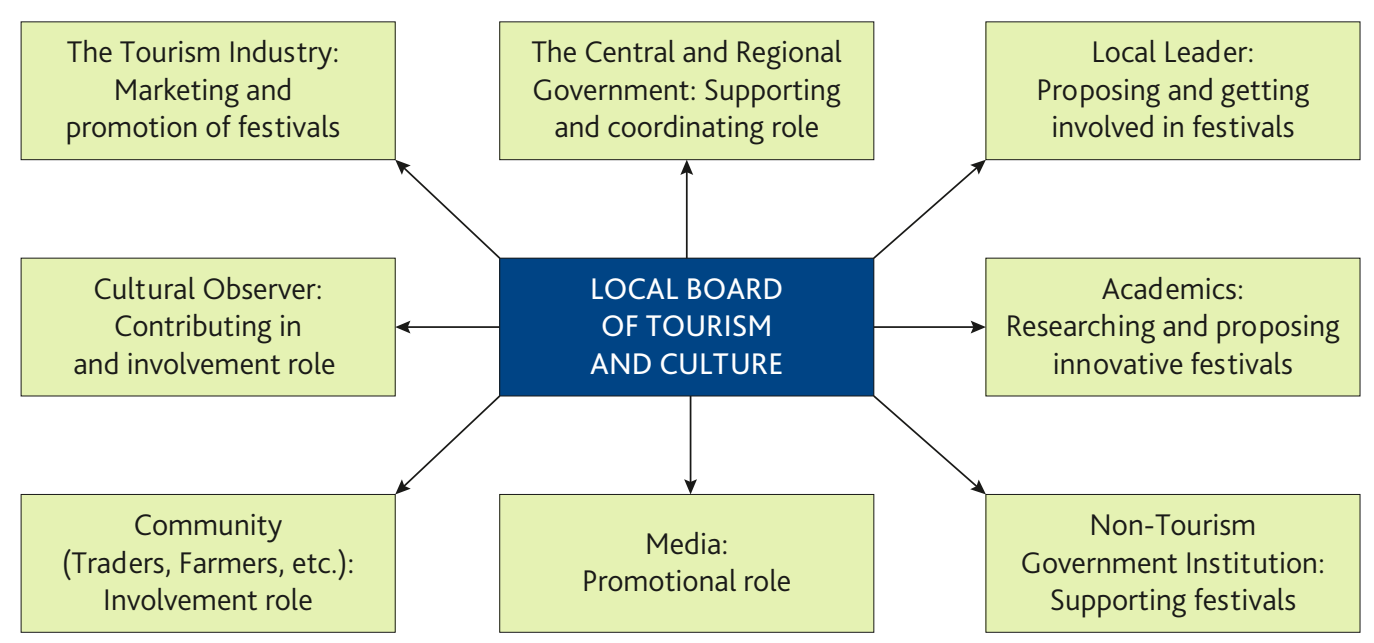

Figure 4. Linking the local board of tourism and culture and groups members of community for innovative festival

Source: Authors, 2017

\section{Conclusion}

Indonesia through the role of the Ministry of Tourism and the regional (local) board of tourism implements different strategies to attract more international tourists. Festivals have become the option of many regencies to promote the existence of natural and cultural potentials including the A'jarang festival in Jeneponto regency. Competition between tourism destinations and the need to increase the awareness of local communities concerning their tourism potential are reasons for creating innovative efforts through tourism. Although the local government realises that the festival is an innovative way, strategies are still needed to achieve the goal of regional tourism development. This paper provides insights into how to improve regional tourism under the framework of tourism innovation.

Four kinds of innovation as proposed by Hjalager (2009) can be the basis for implementing and optimising the ways tourism stakeholders manage tourism. Indeed, the commitment to develop tourism by the local government can become the driver for achieving a country's goal. The local government of Jeneponto regency tries to prove its commitment through a festival. However, the festival should be managed in a way that makes its appeal more global (national and international) rather than local. Innovation in many forms can support the festival into a more global attraction. In addition, the local government as the local authority needs to strengthen relationships with different stakeholders rather than just working with a limited number of stakeholders. 


\section{References}

Barbieri, C., Mahoney, E. 2010. Cultural Tourism Behaviour and Preferences Among the Live-Performing Arts Audience: An Application of the Univorous-Omnivorous Framework. International Journal of Tourism Research 12, 481-496.

Buhalis, D., Ujma, D. 2006. Intermediaries: travel agencies and tour operators. In: Buhalis, D., Costa, C. (Eds.) Tourism Business Frontiers: Consumers, Products and Industry. Elsevier, New York, 171-18o.

Cano, X.P. 2008. Innovation Typology in Tourism. (Master Thesis), Universitat de Girona

Cassela, S. H., Pashkevicha, A. 2014. World Heritage and Tourism Innovation: Institutional Frameworks and Local Adaptation. European Planning Studies 22(8), 1625-1640.

Chaisawat, M. 2006. Policy and Planning of Tourism Product Development in Thailand: A Proposed Model. Asia Pacific Journal of Tourism Research 11(1), 1-16.

Cecil, A. K., Fu, Y.Y., Wang, S., Avgoustis, S. 2010. Cultural Tourism and Quality of Life: Results of a Longitudinal Study. European Journal of Tourism Research 3(1), 54-66.

De Brito, M. P., Terziev, L. 2016. Key Elements for Designing a Strategy to Generate Social and Environmental Value: A Comparative Study of Festivals. Research in Hospitality Management 6(1): 51-59.

Demonja, D. 2013. Cultural Tourism in Croatia After the Implementation of the Strategy of Development of Cultural Tourism. Turizam 17(1), 1-17.

Dredge, D. 2001. Local Government Tourism Planning and Policy-Making in New South Wales: Institutional Development and Historical Legacies. Current Issues in Tourism 4(24), 355-380.

Edwards, D., Martinac, I., Miller, G. 2008. Research Agenda for Innovation in Sustainable Tourism. Tourism and Hospitality Research, 8(1), 56-61.

Fernandes, C. 2013. The impact of cultural tourism on host communities. In: Raj, R., Griffin, K., Morpeth, N. (Eds.) Cultural Tourism. CAB International, Boston, 26-38.

Fyall, A., Garrod, B. 2005. From competition to collaboration in the tourism industry. In: Theobald, W.F. (Ed.) Global Tourism. Elsevier, Amsterdam, 52-74.

Griffin, K.A., Raj, R., Morpeth, N.D. 2013. Introduction to cultural tourism philosophy and management. In: Raj, R., Griffin, K.A., Morpeth, N.D. (Eds.). Cultural Tourism. CAB International, Boston, 1-12.

Hjalager, A. M. 2009. Cultural Tourism Innovation Systems - The Roskilde Festival. Scandinavian Journal of Hospitality and Tourism 9(2-3), 266-287.

Hjalager, A. M. 2006. The Marriage Between Welfare Services and Tourism-A Driving Force for Innovation? Journal of Quality Assurance in Hospitality \& Tourism 6(3-4), 7-29.

Jennings, G.R. 2005. Interviewing: a focus on qualitative techniques. In: Ritchie, B.W., Burns, P., Palmer, C. (Eds.) Tourism Research Methods: Integrating Theory with Practice. CABI, Wallingford, 99-118.

Lee, J-S., Lee, C-K., Choi, Y. 2011. Examining the Role of Emotional and Functional Values in Festival Evaluation. Journal of Travel Research 50(6), 685-696.

Li, Y., Wood, E. H., Thomas, R. 2017. Innovation Implementation: Harmony and Conflict in Chinese Modern Music Festivals. Tourism Management 63, 87-99.

Mallen, C., Adams, L.J. 2008. Sport, Recreation and Tourism Event Management: Theoretical and Practical Dimensions. Elsevier, Oxford.

Mattsson, J., Sundbo, J., Fussing-Jensen, C. 2005. Innovation Systems in Tourism: The Roles of Attractors and Scene-Takers. Industry and Innovation 12(3), 357-381. 
Mei, X. Y., Arcodia, C., Ruhanen, L. 2013. The National Government as the Facilitator of Tourism Innovation: Evidence from Norway. Current Issues in Tourism. doi: 10.1080/13683500.2013.822477

Plog, S.C. 2004. Targeting segments: more important than ever in the travel industry. In: Theobald, W.F. (Ed.) Global Tourism. Elsevier, Amsterdam, 52-74.

Ritchie, J. R. B., Crouch, G. I. 20oo. The Competitive Destination: A Sustainability Perspective. Tourism Management 21, 1-7.

Ruhanen, L. 2013. Local Government: Facilitator or Inhibitor of Sustainable Tourism Development? Journal of Sustainable Tourism 21(1), 80-98.

Sadd, D. 2009. Weymouth's once in a lifetime opportunity. In: Ali-Knight, J., Robertson, M., Fyall, A., Ladkin, A. (Eds.) International Perspectives of Festivals and Events: Paradigms of Analysis. Elsevier, London, 21-40.

Salem, G., Jones, E., Morgan, N. 2004. An overview of events management. In: Yeoman, I., Robertson, M., Ali-Knight, J., Drummond, S., McMahon-Beattie, U. (Eds.) Festival and Events Management: An International Arts and Culture Perspective. Elsevier, Burlington, 14-31.

Shenoy, V. 2016. Branding Innovations for Ideal Placements. International Journal of Management, IT and Engineering (IJMIE) 6(1), 380-387.

Smith, M. K. 2003. Issues in Cultural Tourism Studies. Routledge, New York.

Snape, D., Spencer, L. 2003. The foundations of qualitative research. In: Ritchie, J., Lewis, J. (Eds.) Qualitative Researh Practice: A Guide for Social Science Students and Researchers. SAGE, London, 1-23.

Spencer, L., Ritchie, J., O'Connor, W. 2003. Practices, principles and processes. In: Ritchie, J., Lewis, J (Eds.) Qualitative Research Practice: A Guide for Social Science Students and Researchers. SAGE, London, 199-218.

Tejada, P., Moreno, P. 2013. Patterns of Innovation in Tourism 'Small and Medium-Size Enterprises'. The Service Industries Journal 33(7), 749-758.

Theobald, W.F. 2005. The Meaning, Scope, and Measurement of Travel and Tourism. In: Theobald, W.F. (Ed.) Global Tourism. Elsevier, Amsterdam, 1-5.

Veal, A.J. 2002. Leisure And Tourism Policy And Planning (2nd ed.). CABI, Wallingford.

Wanhill, S., Jansen-Verbeke, M. 2008. Cultural events as catalysts of change; evidence from four European case studies. In: Jansen-Verbeke, M., Priestley, G.K. (Eds.) Cultural Resources for Tourism: Patterns, Processes and Policies. Nova Science Publisher, New York, 155-182.

Wangsyah, R. 2016. Profil Kabupaten Jeneponto Butta Turatea [The Profile of Jeneponto Regency, the Land of Turatea] (in Bahasa Indonesia with English translation) http://www.karebaterkini.com/2016/o2/profil-kabupaten-jeneponto-butta-turatea.html (11/12/2017).

Weiermair, K. 2006. Prospects for Innovation in Tourism. Journal of Quality Assurance in Hospitality \& Tourism 6(3-4), 59-72.

Weidenfeld, A., Butler., Williams, A.M. 2016. Introduction. In: Weidenfeld, A., Butler., Williams, A.M. (Eds.) Visitor Attractions and Events: Locations and Linkages. Routledge, London, 3-17.

Weidenfeld, A., Leask, A. 2016. Innovation in the visitor attraction sectors. In: Weidenfeld, A., Butler., Williams, A.M. (Eds.) Visitor Attractions and Events: Locations and Linkages. Routledge, London, 138-154.

Wood, E.H., Thomas, R. 2009. Festivals and tourism in rural economies. In: Ali-Knight, J., Robertson, M., Fyall, A., Ladkin, A. (Eds.) International Perspectives of Festivals and Events: Paradigms of Analysis. Elsevier, London, 149-185.

Yang, L. 2011. Ethnic Tourism and Cultural Representation. Annals of Tourism Research 38(2), 561-585. 